\title{
Heterodoxies in the Work of János Kornai: How Far from the Mainstream?
}

\begin{abstract}
Balázs Kotosz ${ }^{1}$
Abstract: One of the most important synthetist of the practical socialist theory is János Kornai. In his works he tempted to describe the working mechanism of the socialist economy in actual practice.

The first part of the paper is to gather special keywords and analytical tools of Kornai's description. As economist, the main tool is the description of demand and supply without the mathematical formalization of demand and supply functions, and without any Marshall crosses. Instead of them, the theory is based on quantity (stock, slack, shortage, forced substitution), on friction (caused by rigidity, resistance, and information asymmetry), and on soft budget constraint.

In the second part, we investigate if the tools and keywords correspond to economic streams. The first apprehension is that economy (either capitalist or socialist) is declared to be far from Walrasian equilibrium. The conservators of this "non-equilibrium" steady-state are the different forms of friction. The rigidity is one of the main keywords of the New Keynesian theory, surpassing price rigidity that was headstone of Keynes's General Theory. Kornai attends to the adjustment of quantity (and not, or barely price), but he applies neoclassical analytical tool set (marginal analysis, comparative statics to separate substitution and income effect, etc.) in some (but rare) formal analysis. The soft budget constraint theorem determines the impossibility of neoclassical results because under those conditions the demand theoretically is not limited, but it is in reality. The removal of this contradiction requires devices borrowed from other social sciences.

Finally, the third part sets a question: the characteristics of Kornai's description may be interpreted as the specialty of socialism (i.e. Kornai had no choice, the practical socialism has classical, neoclassical and new Keynesian features), or it is just his own logic that made his analyses such mixed. The answer is double. As Kornai did not take on the mathematical formalization of his theory, he had not to pin down himself to any theoretical economic school. His works about the socialist economy are decisively descriptive, as a non-market economy cannot be seen through the applied neoclassical algebra.
\end{abstract}

Keywords:

János Kornai, socialist economy, non-market process

JEL Classification:

B31, B51, P21, P23

1 PhD, Associate Professor at University of Szeged, Faculty of Economics and Business Administration. Kálvária sgt 1., 6722 Szeged, Hungary. Email: kotosz@eco.u-szeged.hu 


\section{Introduction}

One of the most important synthetist of the practical socialist theory is János Kornai. In his works he tempted to describe the working mechanism of the socialist economy in actual practice. He is the author (or co-author) of more than 200 original books, book chapters and journal articles. His works have been translated to most European and some Asian languages and they are unavoidable not only in the description of the communist system, but in the context of the Eastern European transition from planned towards market economy.

The first general, roundabout publication about the economics of the socialist system was "Economics of Shortage", first published in 1980, the extended and revised version of these ideas are expressed in "The Socialist System. The Political Economy of Communism" (Kornai, [1992b]). Additionally, there is a wide range of papers about the soft budget constraint theory. A series of economists have tried to formalize, to explain or to model this phenomenon. Those publications can be a useful base for understanding the aspects of Kornai's works. In this paper, the main analysis is based on "Economics of Shortage", but also having regard to more recent publications, especially in the context of the theoretical liaisons we use "Market Socialism Revisited".

The paper is constructed as follows. The first part of the paper is to gather special keywords and analytical tools of Kornai's description. In the second part, we investigate if the tools and keywords correspond to economic streams. Kornai attends to the adjustment of quantity (and not, or barely price), but he applies neoclassical analytical tool set (marginal analysis, comparative statics to separate substitution and income effect, etc.) in some (but rare) formal analysis. The removal of the contradiction of not limited demand requires devices borrowed from other social sciences. Finally, the third part answers the question: the characteristics of Kornai's description may be interpreted as the specialty of socialism (i.e. Kornai had no choice, the practical socialism has classical, neoclassical and new Keynesian features), or it is just his own logic that made his analyses such mixed.

\section{Kornai's keywords and analytical tools}

The first part of the paper is to gather special keywords and analytical tools of Kornai's description. The first point is about his titles and scientific style linked to his approach to economic streams. 


\section{1. "I am out of all isms..."}

Kornai has declared in an interview in 1997 that he is out of all "isms", namely he did not join any economic school in his work. His attitude to the economic theory is very clear as he avoided any pure theoretical models in almost his entire scientific curriculum. He has always written "about" something and the description dominated his books and journal articles. The title of only a few paper ${ }^{2}$ listed below suggest real theoretic background:

- The cost functions (1959, Planned Economy in Textile Industry - Textilipari Tervgazdaság)

- Economic System Theory and General Equilibrium Theory (1970, Hungarian Economic Review - Közgazdasági Szemle)

- Equilibrium as a Category of Economics (1982, Hungarian Science - Magyar Tudomány)

- Market Socialism Revisited (1992, book chapter)

- The Concept of the Soft Budget Constraint Syndrome in Economic Theory (1998, Journal of Comparative Economics)

The typical Kornaian titles can be clustered into two groups, in the first he has comments or ideas on actual problems, like:

- Some Ideas about Multi-Level Planning System (1971, Hungarian Economic Review Közgazdasági Szemle)

- On the Ethics of Dispute (1980, Reality - Valóság)

- A Comment (1982, Alcohology - Alkohológia)

- The Hungarian Reform Process: Visions, Hopes and Reality (1986, Journal of Economic Literature)

- Ideas Taken from a Book (1989, Shortage - Hiány)

- Stabilization and Economic Transition in Hungary: The Next Two Years (1991, book chapter)

- Some Ideas on the Situation and Tasks in Hungarian Economic Research and Higher Education (1992, Hungarian Science - Magyar Tudomány)

- The Dilemmas of Hungarian Economic Policy (1995, Hungarian Economic Review Közgazdasági Szemle)

- Suggestions for the Hungarian Health Reform (1998, Critics - Kritika)

- Recommendations for the Hungarian Health Reform (2001, book chapter)

- Comments on Transition: The First Ten Years. Analysis and Lessons (2002, book chapter)

The other type is the mere description, many times expressed also in the title, like:

\footnotetext{
${ }^{2}$ For Hungarian paper titles, we used Kornai's translation, for Hungarian journal names, their official English names, if they have been available.
} 
- A General Descriptive Model of Planning Processes (1970, Economics of Planning)

- The Buyer's Reaction in Case of Commodity Shortage (1975, Hungarian Trade Review)

- Some Properties of the Eastern European Growth Pattern (1981, World Development)

- Descriptive-Explanatory Models of the Socialist Economy. Review of a Research Trend (1982, Sigma)

- Economic Policy and Ethics (1993, Hungarian Science)

It is rather out-of-the-common from an economist to reject any formal approach and to redirect further questions to other sciences like psychology and sociology, but this strategy seems to be more and more accepted in economic science (sub voce Nobel laureates of 2005). We can learn a lot about his aversion from (Kornai, [1992a], 48). In the book chapter he writes "Richness of detail cannot be expected in an intellectual construct belonging to the realm of pure normative theory. But it is not a mere shortcoming, but a fatal fallacy to take the theoretical model too seriously..." Three pages later: "The prototype blueprint [of the socialist planner] is not so naive as the utopian pure theory."

Kornai thinks that the empirical evidence outranges any theory. "Although I admit the relevance of ... pure theoretical models, I would like to point out to Western readers that the practical experience of what took place in the socialist countries cannot be ignored even in the debate at the "visionary" level. The old ideas must be reconsidered in the light of the new evidence." (Kornai, [1992a], 45)

Not only the theory but any numerical views are dismissed: "Rather than going into detail or presenting statistics, just a few of the main characteristics will be emphasized here" (Kornai, [1992a], 48). This approach of avoiding details and statistics is dominating in all his works.

\section{2. Demand and supply "functions"}

His main tool is the description of demand and supply without the mathematical formalization of demand and supply functions, and without any Marshall crosses. Instead of them, the theory is based on the interdependent system of quantity (stock, slack, shortage, forced substitution), of friction (caused by rigidity, resistance, and information asymmetry), and of soft budget constraint.

In his opinion, prices generally are not so important in socialist system, the determinant elements of his work are described in a real economy without prices. This constraint of eliminating prices from the analysis defeats the use of classical demand and supply functions.

The quantity adjustment is an interesting process, and requires additional expressions for the analysis. As there is shortage from some goods, the initial demand can be more than the initial supply. The buyer who cannot buy the goods that initially demanded, will change the initial demand - it is the forced substitution. But she knows that even if at the moment the required goods can be purchased, maybe tomorrow it will not be available, she buys more than it is necessary, resulting slack in the stock-room. So, ex post the final 
demand and supply will be equal, but they are often very far from the initial values. The adjustment is directed by economic rationality, but the equilibrium is not reached by Smith's invisible hand. As the stock of money is not limited for the enterprises (the budget constraint is soft), there is no economically rational limit of the stocks and of the slack. The upper limit of the demand is out of economic rationality, but it can be explained by other social sciences like psychology.

Instead of the market equilibrium quantities Kornai speaks about "normal" or usual quantities. This normal state of the market is a steady-state (the system is stable in longterm around this point), but it is not a Walrasian equilibrium (the initial demand is always greater than supply). The question of steady-state and equilibrium is detailed for example in Denis (2004). Mainstream economists usually agree with this antiequilibrium equilibrium situation only in part. (Kornai, 2014)

Finally, it is important to see that the relative prices are not crucial, but the monetary aggregates - through the soft budget constraint syndrome - are elementary. It is Kornai's specialty that in most cases the unlimited feature of these aggregates play role in economic analysis.

However, there are prices in the socialist economy. It is clear that these prices are not Walrasian prices. By theory, they can be Marxian/Ricardian prices (prime cost + normal profit), or simply administrative and discretionary prices. Most of the prices in the centrally planned economy are of this last type. The state makes efforts to move prices towards Marxian prices, but there is too much friction in the system to achieve this aim. (Kornai, [1980]). Kornai (2014) also argues for sticky prices, even in the capitalist system and in his later works, he cites post-keynesian price theory.

\section{3. Friction (rigidity, resistance, information asymmetry)}

The frictions in Kornai's description are particularly important fields to investigate. The chronic shortage is justified by other factors, the different forms of frictions are blamed for that the steady-state of the economy is not equal to the Walrasian equilibrium.

The main matter is the description of the socialist system, where the role of central planning is crucial. The rigidity of the central planning system at micro or sub-micro level is undoubtful. When an enterprise encounters some shortage on the market of the raw materials, its planned production may become impossible. The central plan cannot be modified, but the spillover effect has consequences at other enterprises and finally it can hit home at the national level plan.

At sub-micro level, the friction appears in the form of estimation error (the buyer cannot forecast exactly the necessary quantity of any goods), the fluctuation of demand (the buyer has good estimation for the yearly demand, but its monthly distribution is unknown; interdependencies in demand of different goods), the asymmetrical information (the buyer does not know where he/she can buy something, so there is slack in a store, while shortage in another), and of course seller's short term rigidity to 
the demand. All these are violating the perfect information assumption, mainly through the temporal and the revelation problem (Mann, 1996)

The resistance is mainly a psychological category: some decisions are made against the market processes, based on individual interests. The fast adaptation to the changing market demand needs fast decisions, often against the central plan. The managers of the state-owned enterprises do not like to tackle the necessary conflicts.

Obviously, these forms of friction are not the special characteristics of the socialist economy. In capitalist economy there are not actors who can perfectly foresee their demand for the 15th July of the next year; any production is rigid in the short term (the technology is fixed in short term), etc. This is why Kornai tells that friction is the cause of the non-Walrasian equilibrium steady-state.

In many of his works, Kornai applies the basic expressions and methods of game theory, like principal-agent model, information asymmetry. The question of the asymmetric information is recrudescent motive of the descriptive models, as - including all real potential factors - it is always true. Theoretically, the information can be free and available for all participants, but in reality, there are always obstacles to know every small detail equally. It is clear with any economic rationality that the information is not free and is not available for all equally. In the existing socialism, even the main economic data were not known for the public (information asymmetry between the state and the enterprises), and it was the same in inter-enterprise or enterprise-consumer relation, too.

\subsection{Soft budget constraint}

The most important scientific innovation from Kornai is the shaping of the soft/hard budget constraint syndrome. The expression is coming from the neoclassical (Walrasian) microeconomics, where the households (consumers) have a budget constraint; they cannot spend more on goods than their income is. In standard microeconomics, this budget constraint is hard, in any circumstances the spending possibilities are limited by the income. Hold on neoclassical microeconomics, there is a budget constraint for the enterprises, as well, even there are different forms of credit, but credits must be paid back.

The soft budget constraint syndrome is based on the socialist enterprise sector. In the system of the state-owned enterprises, any enterprise cannot be liquidated, because the owner (the state) always bails it out by some way: cut of taxes, subsidies, soft loans, etc. At the same time, the budget constraint is hard for the households (and it cannot be soften by credits - formal household credits were almost unknown under the socialist era). The general description of the soft budget constraint is largely detailed at Kornai, and there is a wide literature on soft budget constraint, all authors thinking about the existing socialism or on the transition from planned towards market economy have a definition or description, but at least a not formalized idea about it. As there are many forms of the soft budget constraint, many tools to make the constraint soft, the analysis 
has formal and strictly verbal elements, often with borrowed terms and argumentation from other social sciences.

The soft budget constraint can be also judged in historical time. Modern capitalism has softer budget constraint than it was in the early days of capitalism. If we follow on this idea, the continuously softening constraint can reach a not sustainable level when - in lack of supranational bailout - the globalized capitalist system should collapse. Maybe the Marxian revolution arrives?

Coming back to the definition, we must see that "although the intuitive meaning of soft budget constraint was reasonably clear from the outset, there is still no consensus on a precise definition." (Kornai-Maskin-Roland, [2003], 1095) The microeconomic approach is not neglected, but all type of institution can face the soft budget constraint syndrome: financial intermediaries, non-profit organizations, local governments, and national economies. The currency crises are largely far-reaching events than simple interfirm actions, but this idea helps us to find some microeconomic foundations of macro processes.

The motivation structure of the soft budget constraint is more sophisticated than it can be described by the economic rationality. Over the own best business interest, paternalism, political and reputation incentives, to avoid spillover effects (and finally for example currency crises), and corruption can be the base of the phenomenon. Kornai does not skip the possibility to mention that "no existing model is rich enough to capture all the characteristic features ... of the soft budget constraint" (Kornai-Maskin-Roland, [2003], 1107). At the same time, all known soft budget constraint models (e.g. formal, mathematical models) are principal-agent models, in game theory approach. (See our remarks about the game theory approach earlier.)

\section{Main economic streams and Kornai}

In this part of the paper, we investigate if the tools, keywords and concepts correspond to economic streams. The first apprehension is that economy (either capitalist or socialist) is declared to be far from Walrasian equilibrium. At first look, this take-off excludes all neoclassical theories, but it is not the case.

Kornai declares many times that the goal of his construction is to ram up the lack of a positive theory of politico-socioeconomic order. Any model (like Walrasian, or its later variants like the Lange model of market socialism) has a normative function "placed in a vacuum". Albeit, he cannot avoid crossing continuously the above mentioned formal tools of the economy. He does not do anything for a normative theory, but he beholds the mote in his brother's eye: "A major shortcoming of the literature on the soft bud get constraint is the absence of a systematic exploration of normative implications." (Kornai-Maskin-Roland, [2003], 1132) Great casting! Kornai makes the pure description and the rest of the world should make the overall, complete, and perfect theory to be rejected by Kornai. 


\section{1. Classical ideas, neoclassical tools}

As we discussed in 1.2, the classical idea of the description of demand and of supply is realized in Kornai's work. However, his ideas are very far from the Walrasian theory, crucially because of the unimportance of relative prices. The idea of the vectorial analysis of the quantity adjustment (we cannot use aggregated measures of stock, slack and shortage) is near to the microeconomic foundations of the neoclassical school.

The general problematic point is that Kornai uses the neoclassical toolset in his analysis from the moment when prices are introduced. The first chapter of his book "Economics of shortage" where prices are included is starting with the analysis of the income and substitution effect (not excluded isoquant curves), and in the light of the softness of budget constraint, with the analysis of different forms of classical-neoclassical demand functions. He concludes that the income effect is missing in the socialist economy. This can be true for the enterprises, but not for the households where the budget constraint is really hard. We think that the effect of limited nature of the final consumption has effect on production, but this type of interdependency is not mentioned in his work.

In Kornai's works, an originally microeconomic tool often comes up, namely the game theory. Generally he rejects this tool, because, in his opinion, any contract of the state can be ratted or renegotiated in the socialist system. Thereby the analysis of the contract between the state-center and the management of the firm is vain. It seems to be an important fault-line between Kornai's work and his opinion about those who used, developed or criticized his work. The game theory approach developments of his ideas are very wide ranged in the literature, mainly in the field of the soft budget constraint syndrome. We suppose that Kornai feels the lack of formalism, but because of some reason, he consequently avoids it.

\section{2. Keynesian rigidity and New Keynesian friction}

The conservators of the "non-equilibrium" steady-state are the different forms of friction. The rigidity is one of the main keywords of the new Keynesian theory, surpassing price rigidity that was headstone of Keynes's General Theory. By Kornai, the main difference between the Keynesian macroeconomics and the Walrasian microeconomics is the assumption about prices: Keynesian prices are fixed, while Walrasian prices are flexible. In this world, the Keynesian heritage is closer to him, as price level is essentially fixed in socialism, and generally prices do not matter in economic decisions, they are largely fixed by the state.

Kornai needs the prices only as monetary aggregate, for the description of block of wages, and the soft budget constraint. Obviously, the definition of the budget constraint would be very difficult without prices and monetary aggregates. 
Figure 1: The main line causality of the socialist system

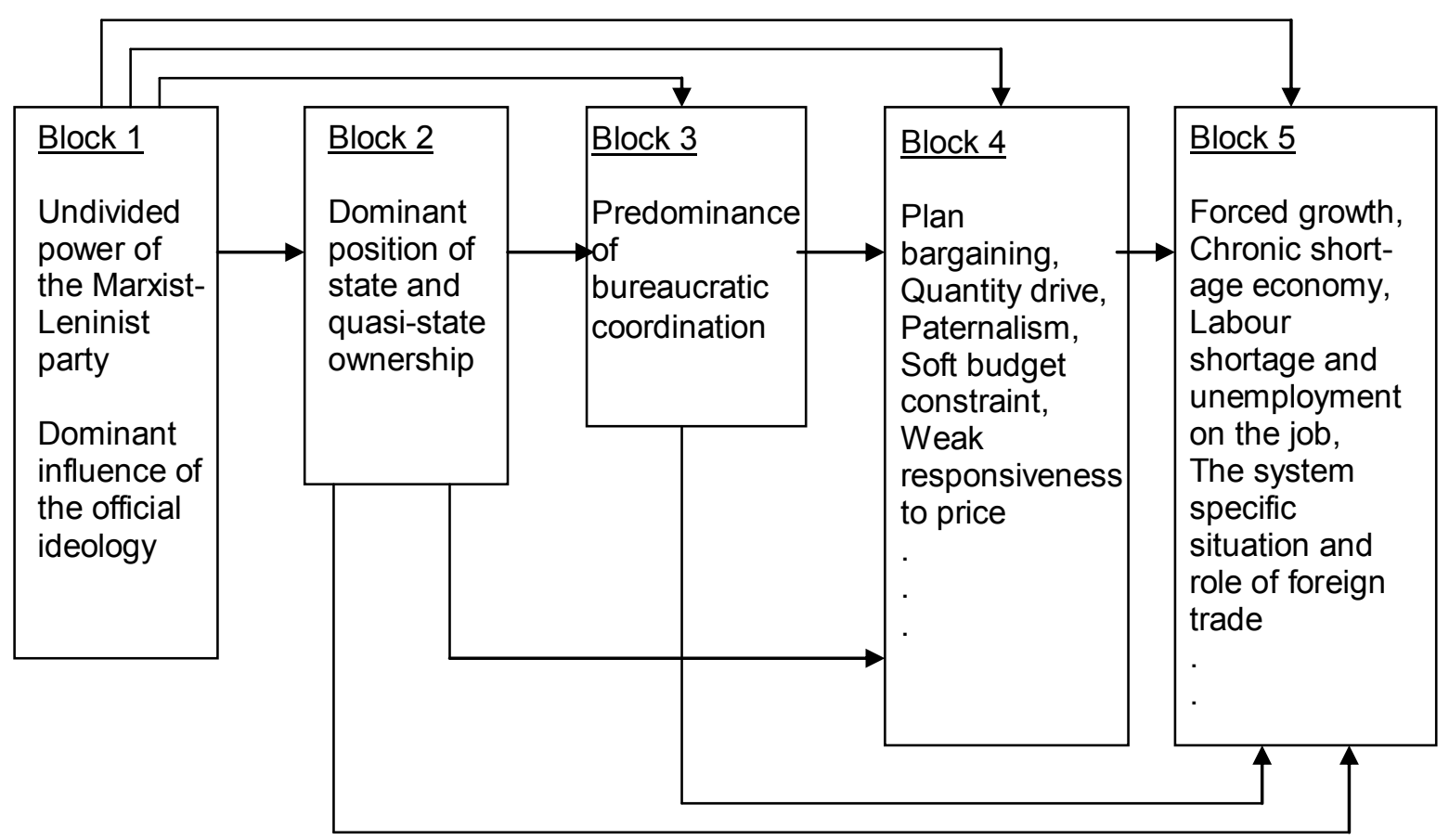

Source: Kornai, [1992b], 361.

The effects of the New Keynesian School on Kornai are very strong in the question of frictions. Not only for the socialist, but for the capitalist economy, frictions are blamed for the non-Walrasian steady-state. At this point, Kornai totally agrees with the New Keynesians, without any remark on this school (in his early works, he could not do it, as the New Keynesian School did not exist, but at the time of millennium, it should have been). A shortcoming of this unanimous harmony is his strong certainty about the fourthly role of the frictions. In the description of the socialist system, they are only in the fourth block of the causality (see Figure 1).

\section{3. Market socialism revisited}

In the socialist theory, two main schools are touched: the Marxism and the market socialism. As Kornai a priori rejects Marxism³, the only interesting question is his attitude to the market socialist theory. It becomes clear from his work entitled "Market socialism revisited" (Kornai, [1992a]). Even if he appreciates some small interesting points, his general theory phobia is stronger, generally he declares to be useless this theory because of its abstraction. But let's see the details!

\footnotetext{
${ }^{3}$ As he expressed in an interview, originally he was strongly Marxist, but at the end of 3 years, he rejected Marxism for a life
} 
Over Kornai's theory phobia, the main problem with his attitude to the market socialism that he identifies the reform socialism existed in the 1980s in some Eastern European countries $^{4}$ as the materialization of the utopia of market socialism. (Kornai, [1992a], Kornai, [1992b]). Concerning price reforms, once he mentions that the Lange model has never been planned to realize (Kornai, [1992b]), but he by-passes this remark everywhere else.

He compares the characteristics of these systems with the Lange model. In his opinion, there are a series of differences and only one common point. The first point is the role of prices, by Lange theory the final central prices should be market clearing, but the reform socialist blueprint fails to say them market-clearing prices. Secondly, the appreciable growth in any sector of reform socialism is the result of privatization, an element missing from the market socialist theory. The reform socialism is accompanied with the shortage-inflation syndrome, while in the classical socialism and in the theory the price level is stable.

The reform socialism (declared to be market socialism) has other negative effects, as well. At the beginning of transition, the earlier reform socialist states (Yugoslavia, Hungary, Poland) were in worse macro situation than resisting (classical socialist) countries (East Germany, Czechoslovakia, Romania). At the end of the transition we can see that the differences of macroeconomic performance of these two groups have been based rather on historical factors (war, unification, separation) than on the years passed in reform socialism.

The role of the state is the next critical point. By the theory, the state is "(1) to determine the market-clearing prices, (2) to enforce the profit-maximization rule for state-owned firms, and (3) to perform some redistribution of personal incomes." (Kornai, [1992a], 49) As Kornai remarks, the role of the state in reality is much wider in the reform socialist era (see section III.2). Otherwise, "it is a false assumption to expect any government ... to maximize the social-welfare function. It is even doubtful whether any well-defined utility function can be assumed." (Kornai, [1992a], 49)

The dynamic or static view is another matter for discussion. The Lange model is static, while reform socialism is a dynamic system, with new rules, actors, etc., the process of the reforms results a continuous change. The only common point is around the static feature of the model and the reality: the problem of entry and exit of firms (changes in the composition of the firms sector) is not well described in Lange model, and practically it is not a real possibility in reform socialism. The impossibility of exit is mainly due to the above explained soft budget constraint syndrome (and not to special regulations or market-clearing prices assuring the market for the products).

The future fortune of the profit of the firm is a crucial question of the market socialist model; see the details of the calculation debate in the 1930s (for summarizing overview,

\footnotetext{
${ }^{4}$ Associated with the names of Tito in Yugoslavia, Kádár in Hungary, Deng Xiaoping in China, Rakowski in Poland and Gorbachev in the Soviet Union.
} 
see Bergson [1967], Jasay [1990], Lavoie [1985]). In the world of state-owned firms, the personal interest to maximize profit is missing. In the lack of adequate incentives, no enterprise manager will make efforts.

Finally, we have to remark that Kornai almost always makes clear the difference of the theory (market socialism) and the practice (reform socialism), but when he speaks about the downfall of the reform socialism in the light of the post-socialist transition, he changes the term, and suddenly it is the failure of market socialism. (Kornai, [1992a], 62)

\section{About the logic of practical socialist system}

Finally, the third part sets a question: the characteristics of Kornai's description may be interpreted as the specialty of socialism (i.e. Kornai had no choice, the practical socialism has classical, neoclassical and New Keynesian features), or it is just his own logic that made his analyses such mixed.

The answer is double. One point is about his motivations and constraints; the other is about the complexity of economy.

\section{1. Political and self-interest motivations}

As Kornai did not take on the mathematical formalization of his theory, he had not to pin down himself to any theoretical economic school. But the causality is into which direction? The answer is not written in his works. Rejecting theoretical economic schools gives him the possibility to avoid critical attacks from the "other side" - and during the existing socialism it was a tool to survive. From the other point of view, the socialist regime preferred simple than sophisticated analytical methods, as the control (censorship) could better check simple methods and description. Special econometric methods had no meaning for bureaucrats of censorship, and increased the probability of rejection. After some decades he used to have that style and has not changed it anymore. The post-socialist transition opened a series of possibilities, but not in his mind about the scientific style. By his autobiography (Kornai, 2007), until 1956 he was pure Marxist (as journalist in the journal of communist party), then he met the neoclassical and mathematical economics, but he rejected it, and from the 1960s, he has been tried to be out of all isms.

\section{2. Complexity of economy, with special regards to socialist economy}

We know that even in the Walrasian economy, the equilibrium can be expressed by solution of a system of linear equations (as much equations as goods we have). One of the main arguments in the calculation debate was the impossibility of solution of a system of equations including millions of equations. If we reject the superiority of economic rationality (as it seems to be necessary in many fields of practical socialism), the system becomes opaque. 
In socialism, the special role of the state makes trouble in any economic analysis. Its functions are:

“- legislator, setting the rules for the economy

- police officer, enforcing the law,

- judge, arbitrating in cases of conflict

- allocator, redistributing wealth and income

- insurer, providing a cushion against risks, a dispenser of social security, and a paternalistic benefactor,

- union official, defending workers from managerial abuse." (Kornai, [1992a], 52)

These aims often are inconsistent. Furthermore, the description is made with actual organizations and actual persons (and not with theoretical ones) whose actions are dictated by their real natures and circumstances. "It is an elementary truth to empirical political scientist that no politician ever has a consistent order of preferences. Unless stupid or stubborn, he or she will improvise, always adjusting to the contingencies, putting one thing first today and another tomorrow." (Kornai, [1992a], 50) Additionally, "If power gets into the hands of power-hungry people, they will use it. Moreover, it has become the tradition and routine for them to do so in the period of classical socialism." (Kornai, [1992a], 52)

We suppose that the coordination mechanism of the economy makes impossible the application of the usual economic modelling tools. In lack of the profit maximizing agent the reasons of bureaucratic coordination (instead of market coordination) are not rational. Kornai's works about the socialist economy are decisively descriptive, as a nonmarket economy cannot be seen through the applied neoclassical algebra.

\section{Concluding remarks}

We can see that Kornai wanted to do more than describing the economics of practical socialism, and more than describing the political economics of the socialist system, he wanted to describe the politico-socio-economic environment of socialism. The complexity of the research may be well marked by the following lines: "The Austrian school certainly offers a richer explanation of these attributes of the socioeconomic order than sterile application of Walrasian theory, but it is still not rich enough. Much can be learnt from Marx if the explanatory theory of the economic order is being examined (although Marx and Hayek are admittedly strange bedfellows)." (Kornai, [1992a], 60)

The reputation of Kornai is two-faced. He is a really open-eyed economist from the point of view of more general social sciences. As he writes: "Economists should make far greater use of the accumulated knowledge offered by modern sociology, political science, social psychology, and history. All this knowledge is required in order to reach the right normative conclusions." (Kornai, [1992a], 60) He makes a lot for being comprehensible to a wider reading public. The most striking example from his book "Economics of shortage" is as on Figure 2. 
But he is a really egocentric economist from the point of view of theoretical issues. As he writes: "It is not the same thing to debate about market socialism in London or Chicago in the 1930s as to debate about it in Budapest, Warsaw, or Moscow today [1992]. The second debate has the special weight; it is greater, richer, and in many ways more convincing than the debate in the 1930s." (Kornai, [1992a], 65)

His theory and formula phobia open the gates towards other - softer - social sciences, but it brings the repugnance to theoretical economists.

Figure 2: Example of economic model from Kornai

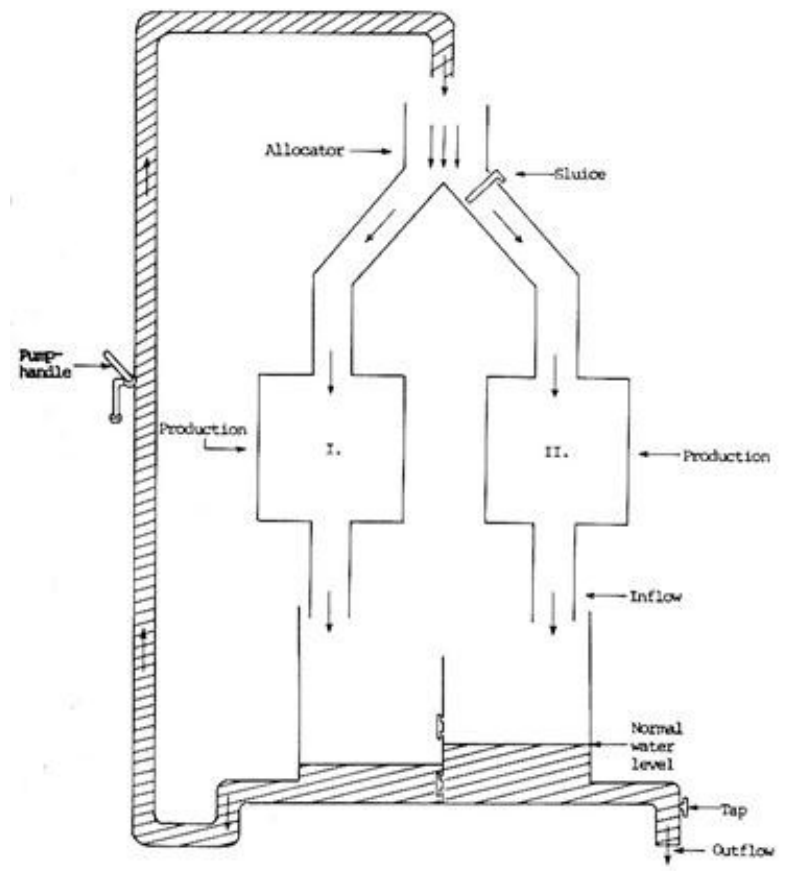

Source: Kornai, [1980], 543.

\section{References}

Bergson, A., 1967. "Market Socialism Revisited", Journal of Political Economy, vol. 75, no. 5, pp. 655-672.

Denis, A., 2004. "The hypostatisation of the concept of equilibrium in neoclassical economics", Paper presented at the annual conference of the Association for Heterodox Economics, Leeds, July 2004.

de Jasay, A., 1990. "Market Socialism: A Scrutiny. «This Square Circle»", Institute of Economic Affairs, London.

Kornai, J., 1971. “Anti-Equilibrium”, North-Holland, Amsterdam.

Kornai, J., 1979. "Resource-Constrained Versus Demand-Constrained Systems", Econometrica, vol. 47, no. 3., pp. 801-819. 
Kornai, J., 1980. "Economics of Shortage", North-Holland, Amsterdam.

Kornai, J., 1992a. "Market Socialism Revisited", in Bardhan P - Roemer J., "Market Socialism: The Current Debate", Oxford University Press, Oxford, pp. 42-68.

Kornai, J., 1992b. "The Socialist System. The Political Economy of Communism", Princeton and Oxford University Press, Oxford.

Kornai, J., Maskin, E., Roland, G., 2003. "Understanding the Soft Budget Constraint", Journal of Economic Literature. vol. XLI, pp. 1095-1136.

Kornai, J., 2007, “By force of thought”, MIT Press, Cambridge.

Kornai, J., 2014, "Dynamism, Rivalry, and the Surplus Economy" Oxford University Press, Oxford.

Lavoie, D., 1985. "Rivalry and Central Planning. The Socialist Calculation Debate Reconsidered", Cambridge University Press, Cambridge.

Mann, R., 1996. "Antimarket economics: blind logic, better science, and the diversity of economic competition", Praeger, Westport. 